Original Article

\title{
INVESTIGATION OF THYROIDS DYSFUNCTION AMONG INFERTILE WOMEN IN NASIRIYAH
} CITY

\author{
MUAYAD HUSSEIN AMER ${ }^{1}$, MAHDI M. THUWAIN ${ }^{1}$, ALI E. AL-SNAFI ${ }^{2}$
}

${ }^{1}$ College of Medical and Healthy Techniques, Southern Technical University-Basrah, ${ }^{2}$ College of Medicine, University of Thi Qar-Iraq Email: aboahmad61@yahoo.com

Received: 17 Jun 2020, Revised and Accepted: 16 Aug 2020

\section{ABSTRACT}

Objective: Epidemiological studies revealed that 10-15 \% of couples in the world experience infertility. Thyroid dysfunction (hyperthyroidism and hypothyroidism) possessed adverse effect on reproductive health and resulted in, interference with ovulation, reduced rates of conception, increased early pregnancy loss, and adverse effects on pregnancy and neonatal outcomes. The current study aims to explore the thyroid dysfunction among infertile women in Nasiriyah city-Iraq.

Methods: The study was conducted on 60 infertile women (age group 17-45 y) who visited infertility departments in Al-Hussein hospital, AlHaboubi hospital and Bent AL Huda hospital, in Nasiriyah city, from October 2019 to March 2020. Thirty normal females (age matched) were taken as controls. TSH, T3, T4, LH, FSH, prolactin, progesterone and estradiol levels were determine by using VIDAS® Assay.

Results: The prevalence of hyperthyroidism among infertile women was $13.33 \%$ and hypothyroidism was $10.00 \%$. Both hyper and hypothyroidism induced adverse changes in the serum levels of LH, FSH, prolactin and gonadal hormones.

Conclusion: Thyroid dysfunction was associated with a risk of not getting pregnancy. Women were advised to achieve euthyroidism before planning a pregnancy.

Keywords: Thyroid dysfunction, Hyperthyroidism, Hypothyroidism, Infertile, Women

(C) 2020 The Authors. Published by Innovare Academic Sciences Pvt Ltd. This is an open access article under the CC BY license (http://creativecommons.org/licenses/by/4.0/) DOI: http://dx.doi.org/10.22159/ijcpr.2020v12i5.39761. Journal homepage: https://innovareacademics.in/journals/index.php/ijcpr

\section{INTRODUCTION}

Infertility is the inability to conceive after one year of regular intercourse without contraception [1]. Epidemiological studies revealed that $10-15 \%$ of couples in the world experience infertility [2]. Thyroid dysfunction (hyperthyroidism and hypothyroidism) possessed adverse effect on reproductive health and resulted in, interference with ovulation, reduced rates of conception, increased early pregnancy loss, and adverse effects on pregnancy and neonatal outcomes [3]. The incidence of both clinical and subclinical hyperthyroidism was $2.3 \%$ of infertile women, compared with an incidence of $1.5 \%$ of women in the general population $[4,5]$. Many studies showed that the prevalence of thyrotoxicosis, of which Graves ' disease was presumably the most frequent, was $0.4 \%$ in the United States, $0.6 \%$ in Italy and $1.1-1.6 \%$ in the United Kingdom [6, 7]. Treatment of thyroid disorders, and maintaining of the thyroidstimulating hormone level at the normal level, improved conception rates and reduce early pregnancy loss $[3,8]$. Thyroid dysfunction can affected female fertility from different ways included hormonal effect [9-12], abnormalities of menstrual cycle [13-17], effect on ovary function and ovulation $[15,18-22]$ and adverse effects on pregnancy $[15,19,23-26]$. The current study aims to explore the thyroid dysfunction among infertile women.

\section{MATERIALS AND METHODS}

The study was conducted on 60 infertile women (age group 17-45 y) who visited infertility departments in Al-Hussein hospital, Al-Haboubi hospital and Bent AL Huda hospital, in Nasiriyah city, from October 2019 to March 2020. Thirty normal females (age matched) were taken as controls. Infertile women (sexually active, not using contraception, and not lactating, who trying for a pregnancy for one years or more). Patients with tubal factors infertility, polycystic ovary syndrome, endometriosis, urogenital tract anomalies, pelvic inflammatory disease, under thyroid disorders or hyperprolactinemia treatments, diabetic, hypertensive and patients with hepatic, cardiovascular and renal diseases were excluded. Patients with abnormal husband's semen analysis were also excluded. The study was approved by the ethical committee of the postgraduate studies of Southern Technical University-Basrah, and performed after taking informed, written consent of the participants [27]

A questionnaire was prepared for each patient to obtain the following information: age, residence, duration of marriage, infertility history (primary, secondary infertility) and duration of infertility [28].

Venous blood ( $5 \mathrm{ml}$ ) was aseptically collected from the infertile and fertile women by venipuncture during the same period in the menstrual cycle (luteal phase) and dispensed into plain bottles (gel tube), allowed to clot, retracted and centrifuged (5000 RPM) for 5 min. The serum obtained was separated and frozen till used for determination of TSH, T3, T4, LH, FSH, prolactin, progesterone and estradiol. Hormonal assays were carried out using VIDAS® Assay.

The statistical analysis was carried out using student-t-test.

\section{RESULTS}

Incidence of hyper and hypothyroidism among infertile women

The prevalence of hyperthyroidism among infertile women was $13.33 \%$ ( 8 of 60 patients) and hypothyroidism was $10.00 \%$ (6 of 60 patients), while $76.67 \%$ (46 of 60 patients) showed a normally functioning thyroid gland. Of euthyroid patients, $6(13.04 \%)$ complained low gonadotropines, $12 \quad(26.08 \%)$ with hyperprolactenemia and $28(60.87 \%)$ showed normal gonadotropines and gonadal hormones levels (table 1).

Characteristics of patients with thyroid dysfunction among infertile women

$50 \%$ of the infertile women with hyperthyroidism were from rural areas and $50 \%$ from the urban areas, while $83.33 \%$ of the infertile women with hypothyroidism were from rural areas and $16.67 \%$ from the urban areas. Of euthyroid infertile women $43.33 \%$ from the rural areas and $56.67 \%$ from urban areas. Primary infertility was recorded in 50, 16.67 and $33.33 \%$ of the infertile women with 
hyperthyroidism, hypothyroidism and euthyroid infertile women, respectively. The mean duration of infertility was 4.87 and 9.25 and
$7.63 \mathrm{y}$ in infertile women with hyperthyroidism, hypothyroidism and euthyroid infertile women respectively.

Table 1: Prevalence of hyper and hypothyroidism among infertile women

\begin{tabular}{llll}
\hline Groups & & Number \\
\hline Infertile & Euthyroid & Low gonadotropines & $6(13.04 \%$ of Euthyroid $)$ \\
women & & Hyperprolactenemia & $12(26.08 \%$ of Euthyroid $)$ \\
& & Normal gonadotropines and prolactin levels & $28(60.87 \%$ of Euthyroid $)$ \\
& Hyperthyroid & 8 & \\
& Hypothyroid & 6 & $13.33 \%$ \\
\hline
\end{tabular}

Correlation between TSH, thyroid hormones and gonadotropines, prolactin and gonadal hormones

Infertile women with hyperthyroidism showed low levels of both serum $\mathrm{LH} 4.482 \pm 1.3 \mathrm{mIU} / \mathrm{ml}(\mathrm{P}<0.05)$ and FSH $4.971 \pm 2.4 \mathrm{mIU} / \mathrm{ml}$ $(\mathrm{P}<0.01)$ compared with control values of $\mathrm{LH} 5.281 \pm 2.3 \mathrm{mIU} / \mathrm{ml}$ and FSH $6.703 \pm 2.5 \mathrm{mIU} / \mathrm{ml}$, while, infertile women with hypothyroidism showed normal FSH $6.385 \pm 3.3 \mathrm{mIU} / \mathrm{ml}$ and significantly declined serum LH level $3.451 \pm 1.7 \mathrm{mIU} / \mathrm{ml}(\mathrm{P}<0.01)$. On the other hand, hormonal analysis of euthyroid infertile women with low gonadotropines levels revealed highly significant declined levels of both $\mathrm{LH} 0.731 \pm 1.6 \mathrm{mIU} / \mathrm{ml}(\mathrm{P}<0.001)$ and FSH levels $1.328 \pm 2.6$ $\mathrm{mIU} / \mathrm{ml} \quad(\mathrm{P}<0.001)$. Euthyroid infertile women with hyperprolactinemia showed mild decline of both LH $4.395 \pm 1.1$ $\mathrm{mIU} / \mathrm{ml}(\mathrm{P}<0.05)$ and $\mathrm{FSH}$ levels $5.495 \pm 2.4 \mathrm{mIU} / \mathrm{ml}(\mathrm{P}<0.05)$. However, only serum LH in euthyroid infertile women with normal gonadotropines and prolactin levels, was declined 4.644 1.0 $\mathrm{mIU} / \mathrm{ml}(\mathrm{P}<0.05)$, while FSH level was in the normal limit $6.385 \pm 3.3$ $\mathrm{mIU} / \mathrm{ml}$ compared with control $6.703 \pm 2.5 \mathrm{mIU} / \mathrm{ml}$. Infertile women with hyperthyroidism showed significantly higher prolactin level $23.555 \pm 4.1 \mathrm{ng} / \mathrm{ml} \quad(\mathrm{P}<0.05)$, while infertile women with hypothyroidism showed normal prolactin levels $19.238 \pm 3.6 \mathrm{ng} / \mathrm{ml}$ compared with control group $18.500 \pm 4.5 \mathrm{ng} / \mathrm{ml}$. In the infertile women with euthyroid, the prolactin level was only elevated significantly in the subgroup of euthyroid with hyperprolactenemia $38.107 \pm 7.5 \mathrm{ng} / \mathrm{ml}(\mathrm{P}<0.001)$, while subgroups euthyroid infertile women with low gonadotropines and normal gonadotropines and prolactin levels showed normal prolactin levels $18.500 \pm 4.5 \mathrm{ng} / \mathrm{ml}$ and $16.511 \pm 3.1 \mathrm{ng} / \mathrm{ml}$ respectively compared with contro $18.500 \pm 4.5 \mathrm{ng} / \mathrm{ml}$. The infertile women with hyperthyroidism and the infertile women with hypothyroidism showed normal serum progesterone level $0.696 \pm 0.3 \mathrm{ng} / \mathrm{ml}$ and $0.765 \pm 0.3 \mathrm{ng} / \mathrm{ml}$, but significantly declined estradiol (E2) level $63.312 \pm 13.1 \mathrm{pg} / \mathrm{ml}$ $(\mathrm{P}<0.01)$ and $53.193 \pm 14.5 \mathrm{pg} / \mathrm{ml}(\mathrm{P}<0.01)$ respectively, compared with control $83.513 \pm 12.1 \mathrm{pg} / \mathrm{ml}$. Progesterone and estradiol (E2) analysis of euthyroid infertile women with low gonadotropines revealed normal estradiol (E2) level $83.600 \pm 214.3 \mathrm{pg} / \mathrm{ml}$ and significantly declined progesterone levels $1.097 \pm 0.2 \mathrm{ng} / \mathrm{ml}(\mathrm{P}<0.05)$ compared with control $0.636 \pm 0.2 \mathrm{ng} / \mathrm{ml}$. However, euthyroid infertile women with hyperprolactinemia showed significantly low serum levels of estradiol (E2) $75.103 \pm 13.4 \mathrm{pg} / \mathrm{ml}(\mathrm{P}<0.05)$, and progesterone level $1.000 \pm 0.1 \mathrm{ng} / \mathrm{ml} \quad(\mathrm{P}<0.05)$, while, euthyroid infertile women with normal serum gonadotropines and prolactin levels showed normal progesterone level $0.816 \pm 0.2 \mathrm{ng} / \mathrm{ml}$ and significantly declined estradiol (E2) level of $62.088 \pm 11.6 \mathrm{pg} / \mathrm{ml}$ $(\mathrm{P}<0.1)$ (table 2).

Table 2: Hormonal analysis of the infertile women

\begin{tabular}{|c|c|c|c|c|c|c|c|c|c|c|}
\hline Groups & & & $\begin{array}{l}\text { TSH } \\
\mathrm{mIU} / \mathrm{ml}\end{array}$ & T3 nmol/l & T4 nmol/l & $\begin{array}{l}\mathrm{LH} \\
\mathrm{mIU} / \mathrm{ml}\end{array}$ & $\begin{array}{l}\text { FSH } \\
\mathrm{mIU} / \mathrm{ml}\end{array}$ & $\begin{array}{l}\text { Prolactin } \\
\text { ng/ml }\end{array}$ & $\begin{array}{l}\text { Progesterone } \\
\mathrm{ng} / \mathrm{ml}\end{array}$ & $\begin{array}{l}\text { Estradiol } \\
\text { (E2) pg/ml }\end{array}$ \\
\hline \multicolumn{3}{|l|}{ Control } & $1.882 \pm 0.9^{a}$ & $1.340 \pm 0.2$ & $88.144 \pm 8.9$ & $5.281 \pm 2.3$ & $6.703 \pm 2.5$ & $18.500 \pm 4.5$ & $0.636 \pm 0.2^{\mathrm{a}}$ & $83.513 \pm 12.1^{a}$ \\
\hline \multirow{5}{*}{$\begin{array}{l}\text { Infertile } \\
\text { women }\end{array}$} & \multirow{3}{*}{ Euthyroid } & $\begin{array}{l}\text { Low } \\
\text { gonadotropines }\end{array}$ & $2.8217 \pm 1.2^{\mathrm{a}}$ & $1.513 \pm 0.3^{\mathrm{a}}$ & $82.458 \pm 10.6^{a}$ & $0.731 \pm 1.6^{\mathrm{b}}$ & $1.328 \pm 2.6^{\mathrm{b}}$ & $16.071 \pm 3.4^{a}$ & $1.097 \pm 0.2^{\mathrm{b}}$ & $83.600 \pm 14.3^{a}$ \\
\hline & & $\begin{array}{l}\text { Hyper- } \\
\text { prolactinemia }\end{array}$ & $2.068 \pm 1.3^{\mathrm{a}}$ & $1.666 \pm 0.4^{b}$ & $85.848 \pm 9.5^{\mathrm{a}}$ & $4.395 \pm 1.1^{\mathrm{c}}$ & $5.495 \pm 2.4^{c}$ & $38.107 \pm 7.5^{b}$ & $1.000 \pm 0.1^{b}$ & $75.103 \pm 13.4^{b}$ \\
\hline & & $\begin{array}{l}\text { Normal } \\
\text { gonadotropines } \\
\text { and prolactin } \\
\text { levels }\end{array}$ & $1.862 \pm 0.9^{a}$ & $1.485 \pm 0.3^{\mathrm{a}}$ & $88.854 \pm 8.9^{a}$ & $4.644 \pm 1.0^{\mathrm{c}}$ & $6.465 \pm 2.6^{\mathrm{a}}$ & $16.511 \pm 3.1^{\mathrm{a}}$ & $0.816 \pm 0.2^{\mathrm{a}}$ & $62.088 \pm 11.6^{c}$ \\
\hline & \multirow{2}{*}{\multicolumn{2}{|c|}{$\begin{array}{l}\text { Hyperthyroid } 8 \text { of } 60 \\
\text { Hypothyroid } 6 \text { of } 60\end{array}$}} & $0.606 \pm 0.2^{b}$ & $1.601 \pm 0.2^{\mathrm{b}}$ & $88.553 \pm 9.1^{\mathrm{a}}$ & $4.482 \pm 1.3^{c}$ & $4.971 \pm 2.4^{c}$ & $23.555 \pm 4.1^{\mathrm{c}}$ & $0.696 \pm 0.3^{\mathrm{a}}$ & $63.312 \pm 13.1^{c}$ \\
\hline & & & $5.545 \pm 1.8^{\mathrm{c}}$ & $1.093 \pm 0.2^{\mathrm{c}}$ & $75.878 \pm 12.4^{b}$ & $3.451 \pm 1.7 \mathrm{c}$ & $6.385 \pm 3.3^{\mathrm{a}}$ & $19.238 \pm 3.6^{a}$ & $0.765 \pm 0.3^{\mathrm{a}}$ & $53.193 \pm 14.5^{d}$ \\
\hline
\end{tabular}

Vertically, different letter means significant variations; the P value was mentioned in the text.

\section{DISCUSSION}

Thyroid hormones play critical roles in growth, differentiation and metabolism. They are important for optimal functioning of almost al tissues with major effects on metabolic rate and oxygen consumption. Thyroid dysfunctions interfere with female reproductive performance. Several studies highlighted the association of hyperthyroidism or hypothyroidism with hormonal disturbances, anovulatory cycles, decreased fecundity and increased lost of pregnancy $[15,17,29]$.

The current study aims to investigate the prevalence of thyroid dysfunction among infertile women. Measurement of thyroid hormones, especially thyroid stimulating hormone, was considered as an important component of infertility work up in women [30]

Serum TSH showed a log-linear relationship to thyroxin. The assay of TSH was commonly used as the most sensitive test to detect minor degrees of primary thyroid hormone abnormalities [31].
The study showed that the incidence of hyperthyroidism among infertile women was $13.33 \%$ (8 of 60 patients) and hypothyroidism was $10.00 \%$ ( 6 of 60 patients), while $76.67 \%$ (46 of 60 patients) showed normally functioning thyroid gland. However, many previous studied mentioned that hyperthyroidism is thought to be found in $2.3 \%$ of women with subfertility, compared with an prevalence of $1.5 \%$ of women in the general population $[4,5]$. The prevalence of thyrotoxicosis was $0.4 \%$ in the United States, $0.6 \%$ in Italy and $1.1-1.6 \%$ in the United Kingdom $[6,7]$. The high prevalence of thyroid dysfunction in this study in comparison with the mentioned studies could be attributed to general high prevalence of hyperthyroidism in the studied population $[32,33]$.

In addition, the previous studied deal with clinical cases only, while in this study we included all the clinical and subclinical hypo and hyperthyroidism cases. However, the majority of the tested infertile women in our study showed normal thyroid function $(76.67 \%)$. These results were in agreement with Goswami et al., who found 
that the majority of the infertile women were euthyroid. In infertile group, the prevalence of thyroid dysfunction was slightly higher than that of the general population [20].

Our study revealed that TSH level in infertile women with hyperthyroidism was significantly lower $(0.606 \pm 0.2)$, while, significantly higher in infertile women with hypothyroidism $(5.545 \pm 1.8)$ than in control group $(1.882 \pm 0.9)$. Correlation of prolactin level with thyroid function showed that hyperthyroidism (but not hypothyroidism) associated with significantly higher level of prolactin, $23.555 \pm 4$.1 $(\mathrm{P}<0.05)$.

These results were in agreement with many studies, showed that serum prolactin was significantly $(\mathrm{P}<0.05)$ higher in infertile group with thyroid dysfunction compared with control $[9,20,34]$.

Many previous studies revealed that there was a positive correlation between serum TSH and prolactin levels in the infertile subjects. Hyperprolactinemia was depicted in $41 \%$ of the infertile women while it was only $15 \%$ in the control group. The infertile women with hypothyroidism had significantly higher prolactin levels when compared to the subjects with hyper-or euthyroidism $[9,20]$.

TRH regulated the levels of cytoplasmic prolactin mRNAs in a line of functional rat pituitary cells. Prolactin mRNA increased from 1.1 to $4.5 \%$ within $48 \mathrm{~h}$ after addition of TRH to the medium) suggested that TRH was responsible for the stimulation of prolactin mRNA levels $[35,36]$.

Our study showed declined level of LH, FSH and estradiol (E2) levels in the infertile women with hypothyroidism, hyperthyroidism and hyperprolactinemia. These data in agreement with Liu et al., who found that the serum levels of gonadotropin releasing hormone (GnRH) and follicle stimulating hormone (FSH) in both hypo-and hyperthyroidism rat models were significantly decreased on the luteal phase, although there were no significant changes at earlier time points. There were no significant differences in luteinizing hormone $(\mathrm{LH})$ or progesterone levels between the treatment and the control groups [9].

These effects could be attributed to the elevated level of prolactin in the infertile women with hyperprolactinemia and hypo and hyperthyroidism.

It is well documented that hyperprolactinemia interferes with the female reproductive function, the mechanism by which hyperprolactinemia interferes with the normal hypothalamic-pituitary-ovarian axis, leading to menstrual abnormalities and anovulation. Hypeprolactinemia interferes at hypothalamic level with the GnRH release; this was suggested by studies showing failure of estrogen to elicit a positive feedback on gonadotropines secretion; however other studies showed diminished fluctuation pattern of LH secretion. Hypeprolactinemia may also act at the pituitary level by desensitizing it to GnRH effect and decreases FSH and LH release from anterior pituitary. Hypeprolactinemia also possesses direct effect of on the ovaries and interferes with steroidegenesis [37]

\section{CONCLUSION}

The prevalence of hyperthyroidism among infertile women was $13.33 \%$ and hypothyroidism was $10.00 \%$. Both hyper and hypothyroidism induced adverse changes in the serum levels of $\mathrm{LH}$ FSH, prolactin and gonadal hormones. Thyroid dysfunction was associated with a risk of not getting pregnancy. Women were advised to achieve euthyroidism before planning a pregnancy.

\section{FUNDING}

Nil

\section{AUTHORS CONTRIBUTIONS}

All the authors have contributed equally.

\section{CONFLICT OF INTERESTS}

\section{Declared none}

\section{REFERENCES}

1. Barbieri R. Female infertility. In: Strauss J, Barbieri R. (eds). Yen and Jaffe's Reproductive Endocrinology: Physiology,
Pathophysiology, and Clinical Management. $6^{\text {th }}$ ed. Philadelphia, PA: Elsevier; 2009.

2. Evers JLH, Collins JA. Assessment of efficacy of varicocele repair for male subfertility: a systematic review. Lancet 2003;361:1849-52.

3. Khar A, Taverny Bennardo T, Jutisz M. Effect of thyroid hormones on gonadotrophin release and biosynthesis using rat pituitary cell culture. J Endocrinol 1980;85:229-35.

4. Poppe K, Glinoer D, Van Steirteghem A, Tournaye H, Devroey P, Schiettecatte J, et al. Thyroid dysfunction and autoimmunity in infertile women. Thyroid 2002;12:997-1001.

5. Bjoro T, Holmen J, Kruger O, Midthjell K, Hunstad K, Schreiner $\mathrm{T}$, et al. Prevalence of thyroid disease, thyroid dysfunction and thyroid peroxidase antibodies in a large, unselected population. The health study of nord-trondelag (HUNT). Eur J Endocrinol 2000;143:639-47.

6. Aghini Lombardi F, Antonangeli L, Martino E, Vitti P, Maccherini D, Leoli F, et al. The spectrum of thyroid disorders in an iodine-deficient community: the pescopagano survey. J Clin Endocrinol Metab 1999;84:561-6.

7. Furszyfer J, Kurland LT, McConahey WM, Woolner LB, Elveback LR. Epidemiologic aspects of Hashimoto's thyroiditis and graves' disease in rochester, minnesota (1935-1967), with special reference to temporal trends. Metabolism 1972;21:197-204.

8. Krassas GE, Poppe K, Glinoer D. Thyroid function and human reproductive health. Endocr Rev 2010;31:702-55.

9. Liu J, Guo M, Hu X, Weng X, Tian Y, Xu K, et al. Effects of thyroid dysfunction on reproductive hormones in female rats. Chinese Physiol 2018;61:152-62.

10. Veeresh T, Moulali D, Sarma DHS. A study on serum FSH, LH and prolactin levels in women with thyroid disorders. Int J Sci Res Publications 2015;5:1-4.

11. Jefferys A, Vanderpump M, Yasmin E. Thyroid dysfunction and reproductive health. Fertility Assisted Reproduction Primary Care 2015;17:39-45.

12. Hatsuta M, Tamura K, Shimizu Y, Toda K, Kogo H. Effect of thyroid hormone on CYP19 expression in ovarian granulosa cells from gonadotropin-treated immature rats. J Pharmacol Sci 2004; $94: 420-5$

13. Akinci B, Comlekci A, Ozcan MA. The alteration of coagulation in patients with thyroid dysfunction. Recent Pat Endocr Metab Immune Drug Discovery 2011;5:50-7.

14. Poppe K, Velkeniers B, Glinoer D. Thyroid disease and female reproduction. Clin Endocrinol (Oxf) 2007;66:309-21.

15. Poppe K, Velkeniers B, Glinoer D. The role of thyroid autoimmunity in fertility and pregnancy. Nat Clin Pract Endocrinol Metab 2008; 4:394-405.

16. Poppe K, Velkeniers B. Thyroid disorders in infertile women. Ann Endocrinol (Paris) 2003;64:45-50.

17. Koutras DA. Disturbances of menstruation in thyroid disease. Ann N Y Acad Sci 1997;816:280-4.

18. Mattheij JA, Swarts JJ, Lokerse P, Van Kampen JT, Van der Heide D. Effect of hypothyroidism on the pituitary-gonadal axis in the adult female rat. J Endocrinol 1995;146:87-94.

19. Gude D. Thyroid and its indispensability in fertility. J Hum Reprod Sci 2011;4:59-60.

20. Goswami B, Patel S, Chatterjee M, Koner BC, Saxena A Correlation of prolactin and thyroid hormone concentration with menstrual patterns in infertile women. J Reprod Infertil 2009;10:207-12.

21. Aghajanova L, Lindeberg M, Carlsson IB, Stavreus Evers A Zhang P, Scott JE, et al. Receptors for thyroid-stimulating hormone and thyroid hormones in human ovarian tissue. Reprod Biomed Online 2009;18:337-47.

22. Jiang JY, Umezu M, Sato E. Improvement of follicular development rather than gonadotrophin secretion by thyroxine treatment in infertile immature hypothyroid rdw rats. J Reprod Fertil 2000;119:193-9.

23. Feldthusen A, Pedersen PL, Larsen J, Kristensen TT, Ellervik C, Kvetny J. Impaired fertility associated with subclinical hypothyroidism and thyroid autoimmunity: the danish general suburban population study. J Pregnancy 2015. http://dx.doi.org/10.1155/2015/132718. 
24. Cignini P, Cafa EV, Giorlandino C, Capriglione S, Spata A, Dugo N. Thyroid physiology and common diseases in pregnancy: review of literature. J Prenat Med 2012;6:64-71.

25. Davis LB, Lathi RB, Dahan MH. The effect of infertility medication on thyroid function in hypothyroid women who conceive. Thyroid 2007;17:773-7.

26. Casey BM, Leveno KJ. Thyroid disease in pregnancy. Obstet Gynecol 2006;108:1283-92.

27. Verma I, Sood R, Juneja S, Kaur S. Prevalence of hypothyroidism in infertile women and evaluation of response of treatment for hypothyroidism on infertility. Int J Appl Basic Med Res 2012;2:17-9.

28. Udgiri R, Patil VV. Comparative study to determine the prevalence and socio-cultural practices of infertility in rura and urban field practice area of tertiary care hospital, Vijayapura, Karnataka. Indian J Community Med 2019;44:129-33.

29. Doufas AG, Mastorakos G. The hypothalamic-pituitary-thyroid axis and the female reproductive system. Ann N Y Acad Sci 2000;900:65-76

30. Cramer DW, Sluss PM, Powers RD, McShane P, Ginsburgs ES, Hornstein MD, et al. Serum prolactin and TSH in an in vitro fertilization population: is there a link between fertilization and thyroid function? J Assist Reprod Genet 2003;20:210-15.
31. Blumenthal NJ, Eastman CJ. Beneficial effects on pregnancy outcomes of thyroid hormone replacement for subclinical hypothyroidism. J Thyroid Res 2017:1-7. DOI: org/10.1155/2017/4601365.

32. Al-Seidi FA, Jarullah BA. Diagnosis of hypothyroidism depending upon signs and symptoms design scoring system. J Thi-Qar Sci 2014;4:10-3.

33. Hasin AJ, Ayyed MY, Farawn KD. Histopathological characters of solitary thyroid nodule in patient undergoing surgery at $3 \mathrm{y}$ (2015-2017) in Al-Nasiriyah city. Thi Qar Med J 2019;17:145-57.

34. Frayyeh MJ, Fakhridin MBMR, Al-Lami MQD. The prevalence of autoimmune thyroiditis in a sample of infertile Iraqi women. Iraqi J Sci 2014;55:1183-7.

35. Barbieri RL, Cooper DS, Daniels GH, Nathan D, Klibanski A, Ridgway C. Prolactin response to thyrotropin-releasing hormone (TRH) in patients with hypothalamic-pituitary disease. Fertility Sterility 1985;43:66-73.

36. Evans GA, David DN, Rosenfeld MG. Regulation of prolactin and somatotropin mRNAs by thyroliberin. Proc Nadl Acad Scd USA 1978;75:1294-8.

37. Al-Snafi AE, Al-Baldawi AT, Al-Rubaei AK. The efficacy of bromocriptine with and without ovarian stimulation in the treatment of hyperprolactinemic infertile women. Middle East Fertility Society J 2003;8:1-4. 